\title{
Lupus Erythematosus Cells in Bone Marrow: The Only Clue to a Previously Unsuspected Diagnosis of Systemic Lupus Erythematosus
}

\author{
Mukta Pujani Shivani Kushwaha Neha Sethi Anu Beniwal Shailaja Shukla \\ Department of Pathology, Lady Hardinge Medical College and Smt. Sucheta Kriplani Hospital, New Delhi, India
}

\section{Established Facts}

- Systemic lupus erythematosus (SLE) is diagnosed via antinuclear antibody tests (anti-double stranded DNA, anti-Smith antibody). Earlier, demonstration of the lupus erythematosus (LE) cell phenomenon via the buffy coat method or the defibrination method was used as a preliminary test for SLE.

\section{Novel Insights}

- LE cells can rarely be detected in bone marrow films spread immediately without the use of anticoagulants, incubation, or any other manipulation, which is an exceptional finding reported very rarely in the literature.

- Good cytological observation of marrow aspirates can provide crucial clues to a previously unsuspected diagnosis.

\section{Key Words}

Systemic lupus erythematosus - Lupus erythematous cell · Bone marrow aspirate

\footnotetext{
Abstract

Background: Systemic lupus erythematosus (SLE) is an autoimmune multisystem disease characterized by the development of antinuclear antibodies. Nowadays considered outdated, lupus erythematosus (LE) cell preparation served as a screening test for SLE for decades. However, the importance of discovering LE cells on routine cytology cannot be overemphasized. Case: We report the case of a 30-year-old
}

female in whom bone marrow aspiration (BMA) was performed during an investigative workup for pyrexia of unknown origin. The observation of LE cells in direct bone marrow smears (without the use of an anticoagulant) raised the suspicion of SLE, which was later confirmed by antinuclear antibody testing. Conclusion: In the present case, LE cells were observed on BMA performed for the investigation of fever of unknown origin. The unexpected observation of LE cells in BMA smears emphasizes the fact that good morphological observation of marrow aspirates can provide crucial clues to a previously unsuspected diagnosis.

(c) 2013 S. Karger AG, Base

\section{KARGER}

E-Mail karger@karger.com

www.karger.com/acy
(C) 2013 S. Karger AG, Basel

$0001-5547 / 13 / 0576-0652 \$ 38.00 / 0$
Correspondence to: Dr. Mukta Pujan

Department of Pathology

Hamdard Institute of Medical Sciences and Research

New Delhi 110062 (India)

E-Maildrmuktapujani@gmail.com 


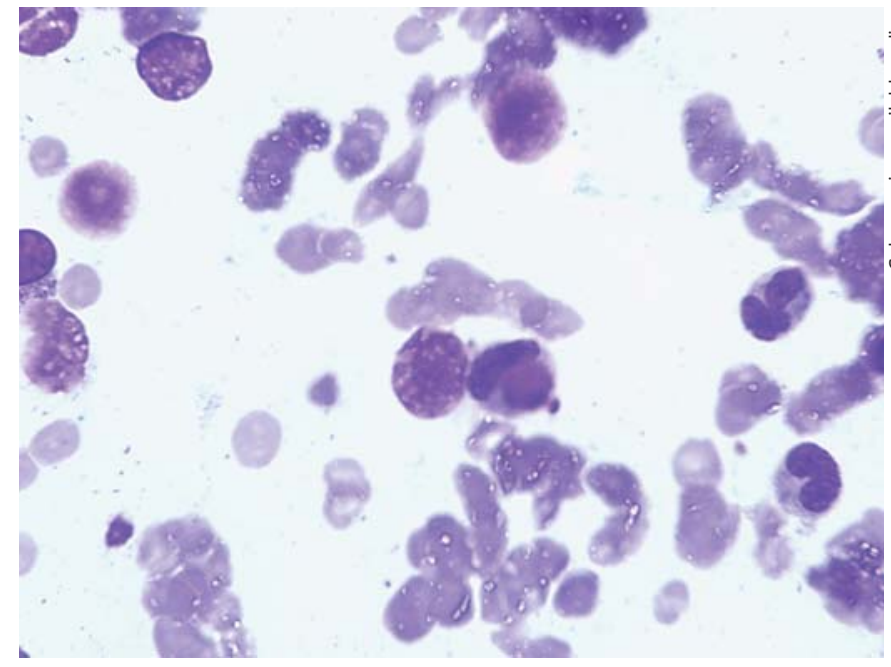

Fig. 1. Photomicrograph showing occasional LE cells in bone marrow films spread directly without the use of anticoagulants. Giemsa. $\times 400$.

\section{Background}

Systemic lupus erythematosus (SLE) is an autoimmune multisystem disease characterized by the development of autoantibodies particularly against proteins in the cell nucleus. Earlier, lupus erythematosus (LE) cell preparation was used as a screening test for SLE, but it is not specific and has now been replaced by antinuclear antibody tests as the confirmatory test for SLE. We hereby report a case where the diagnosis of SLE was triggered by the detection of LE cells in bone marrow aspirate (BMA) smears prepared immediately without any manipulation.

\section{Case}

A 30-year-old female presented with the chief complaint of continuous low-grade fever for 1 year, associated with easy fatiguability, amenorrhea and nonpitting edema of bilateral lower limbs for a couple of months. On general physical examination, the patient was pale, with mild splenomegaly; however, there was no lymphadenopathy or hepatomegaly. A provisional clinical diagnosis of malaria/kala-azar was considered. Hematological investigations revealed: hemoglobin $5.2 \mathrm{~g} \%$, total leucocyte count $4.7 \times 10^{3} /$ $\mu \mathrm{l}$, and platelet count $164 \times 10^{3} / \mu \mathrm{l}$. Peripheral blood smears showed normocytic normochromic red cells and neutrophilia with a mild shift to the left. No hemoparasites were seen. BMA smears were cellular with normoblastic erythroid hyperplasia, normal myeloid maturation, and adequate megakaryopoesis. There was a mild increase in the number of mature plasma cells. On careful scrutiny, a few scattered LE cells were noted on BMA smears (fig. 1, 2), which were further confirmed on LE cell preparation (fig. 3). The possibility of SLE was suggested on BMA smears. Indirect immu-

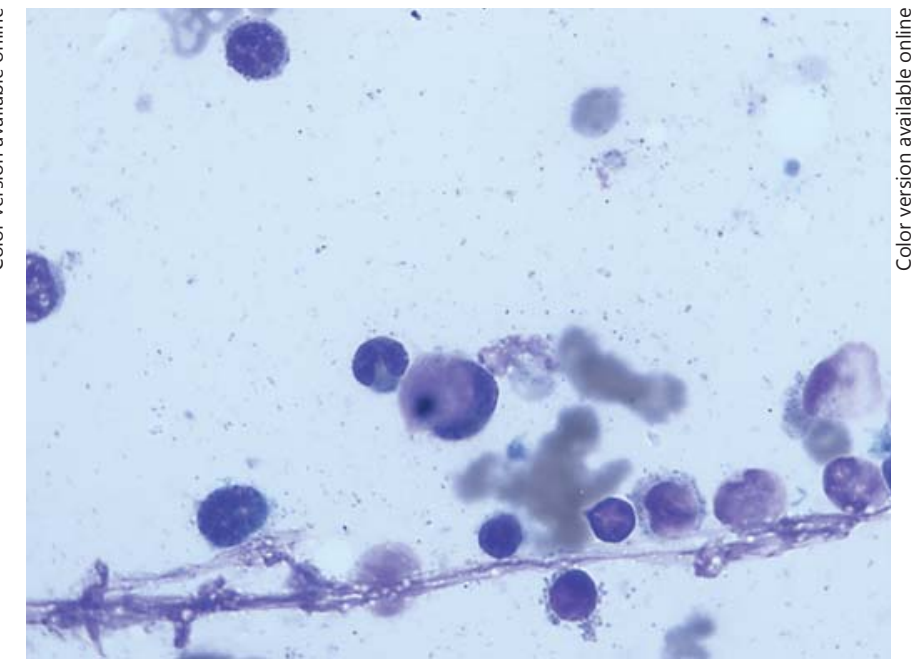

Fig. 2. Photomicrograph showing a more typical LE cell in direct marrow films. Giemsa. $\times 400$.

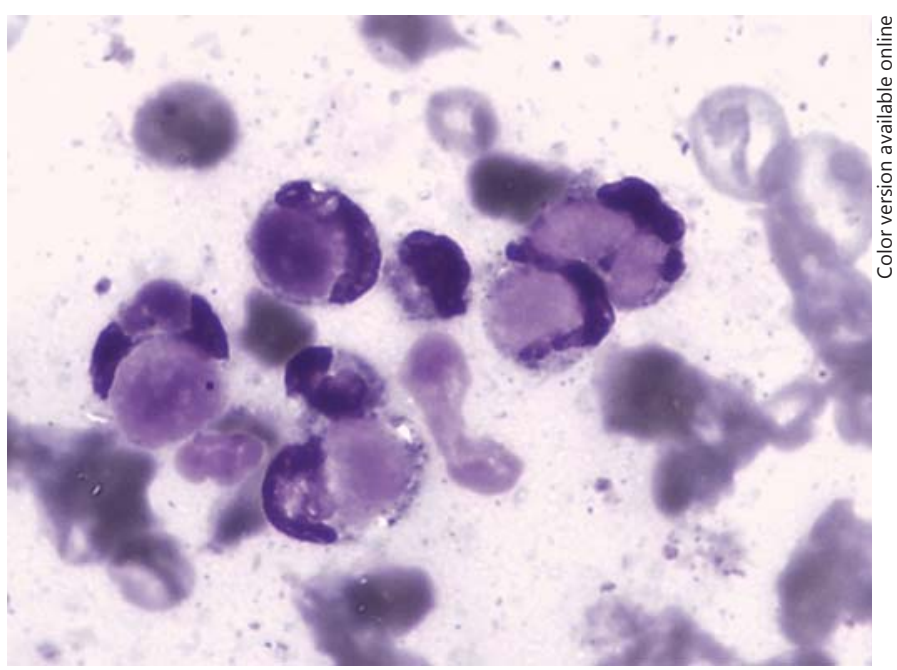

Fig. 3. Photomicrograph showing numerous LE cells in an LE cell preparation. Giemsa. $\times 400$.

nofluorescence studies revealed diffusely positive ANA along with anti-double standard DNA, antihistone, anti-Scl-70, SS-A (Ro), and SS-B (La), thus confirming SLE as the final diagnosis.

\section{Discussion}

The LE cell consists of a leucocyte, almost invariably a neutrophil, which contains a large, spherical, opaque, homogenous body in the cytoplasm. Hargraves et al. [1] first 
described the LE cell in 1948 in the BMA of patients with disseminated LE. Sundberg and Lick [2] demonstrated LE cells in buffy coat preparations in patients with SLE. Moreover, Eppes and Ludovic [3] observed LE cells in SLE patients without the use of anticoagulants; however, they used concentration techniques like defibrinated blood and unmodified blood in silicon coated tubes.

LE cell formation is a multistage process requiring four distinct elements, namely nuclear substrate, antinuclear factor or LE factor, phagocytic cell, and complement [4]. The LE cell, initially considered apparently specific for SLE, has been observed in other conditions like rheumatoid arthritis, nephritis, chronic hepatitis, thyroiditis, Sjogren's syndrome, pernicious anemia, ulcerative colitis, red cell aplasia, mixed connective tissue disease, etc. [5]. LE cell preparation has now been virtually replaced by much more specific tests like antinuclear antibody tests (anti-double stranded DNA, anti-Smith antibody) in the diagnosis of SLE.
We hereby present a case of SLE where the diagnosis of SLE was triggered by the observation of LE cells in BMA smears. Specific LE cells have been rarely reported in bone marrow smears if the sample is anticoagulated and there is a delay in the spreading of films $[6,7]$. On the contrary, in the index case, the LE cells were detected in bone marrow films spread immediately without the use of anticoagulants, incubation, or any other manipulation. During an extensive search of the literature, we came across the occasional report where LE cells were observed in direct bone marrow films [8]. LE cells can occasionally be observed in fine-needle aspiration cytology from lymph nodes in cases of SLE [9].

This case highlights the fact that LE cells, when observed in direct bone marrow films in clinically unsuspected cases of SLE, can provide a very important clue for the diagnosis of SLE. Though the LE cell test has now become redundant, it can still act as a crucial indicator for ordering specific and confirmatory tests for the diagnosis of SLE in clinically atypical cases.

\section{References}

$>1$ Hargraves MM, Richmond H, Morton R: Presentation of two bone marrow elements: the 'tart' cell and 'LE' cell. Proc Staff Meet Mayo Clin 1948;23:25-28.

-2 Sundberg RD, Lick NB: LE cells in the blood in acute disseminated lupus erythematosus. J Invest Dermatol 1949;12:83-84.

$>3$ Eppes W, Ludovic E: Demonstration of the LE cell without use of anticoagulants. Blood 1951;6:466-469.
4 Koller SR, Johnston CL Jr, Moncure CW: Lupus erythematosus cell preparation-antinuclear factor incongruity: a review of diagnostic tests for systemic lupus erythematosus. Am J Clin Pathol $1976 ; 66: 495-505$.

$\checkmark 5$ Oduola T, Uchegbu OO, Arogundade FA, Bello IS, Akinjole OO, Avwioro OG: Prevalence and pattern of lupus erythematosus cell positivity in diseases in Ile-Ife, Nigeria. Afr J Biomed Res 2005;8:135-137.

66 Ghevaert C, Oscier D, Hopkinson N: History revisited. Br J Hematol 2003;123:756.
7 Ferrario C, Quaroz S, Angelillo-Scherrer A: Diagnosis of systemic lupus erythematosus by bone marrow cytology. 2008. http:/www. bloodmed.com/home/allslideatlas.asp.

$>$ Abdulsalam AH, Sabeeh N, Hatim A, Bain BJ: Diagnosis of systemic lupus erythematosus from a bone marrow aspirate. Am J Hematol 2012;87:620.

9 Pai MR, Adhikari P, Coimbatore RVR, Ahmed S: Fine needle aspiration cytology in systemic lupus erythematosus lymphadenopathy. Acta Cytologica 2000;44:67-69. 